\title{
Huoer of Tibetan Culture and Its Application in Landscape Architecture
}

\author{
Miao Tan \\ Sichuan Agricultural University \\ Chengdu, China \\ Ai Cheng \\ Sichuan Agricultural University \\ Chengdu, China \\ Yi-Mei Feng \\ Sichuan Agricultural University \\ Chengdu, China
}

\author{
Qing Wu \\ Sichuan Agricultural University \\ Chengdu, China \\ Xiao-Min Chen \\ Sichuan Agricultural University \\ Chengdu, China \\ Xiao-Fang $\mathrm{Yu}^{*}$ \\ Sichuan Agricultural University \\ Chengdu, China
}

\begin{abstract}
Huoer culture, which is located in "Huoer Zhang valley" of Western Sichuan Plateau that is the ancient Tibetan and Yi corridor, has a history of thousands of years. But it has disappeared in the vast history since ancient time nearest to the present, no one to ask. The author had the opportunity to participate in the planning and design of "Huoer Zhang valley wetland park", thus to understand the ancient mysterious and of long standing culture. The paper, combined with the experience of the author, by looking up a large number of ancient books and records, knowing the local scholars oral and going on some field research, attempts to make generalizations of the Huoer culture.
\end{abstract}

Keywords-Huoer culture; Huoer Zhang valley; landscape architecture

\section{INTRODUCTION}

As the global integration, it brings about huge impact on our local traditional culture gradually. The impact reflects not only on the aesthetic demands and value orientation, but in the aspect of regional material space. It separates the performance of science and technology and humanities spirit, and it leads to the local characteristics of culture previously slow formed under the condition of regional are fast disappearing. Both in terms of ecological environment, landscape planning and urban development and construction projects, etc are exposed the negativity. These negative prompt relevant experts and scholars begin to research into the thinking of exploring local culture protection and inheriting the way of moving forward ${ }^{[1]}$. In allusion to the current local characteristic culture impact and survival threat, It is imminent to protect and inherit ethnic minority regional cultures.

There is on doubt that Landscape Architecture Design is a good cultural carrier. It can not only inheriting regional culture, but helping regional culture to carry forward. The author has the opportunity to participate in the Huoer Zhang valley in Luhuo county wetland park planning and design. Besides, in the process of planning and design, the author gives an insight into the local Huoer cultural and integrates it into landscape design. He hopes to be able to explore new train of the traditional regional culture element thought on the exploration, development and protection.

\section{THE SOURCE OF "HuOER" AND "HuOER CUlture"}

\section{A. The Brief Introduction of Huoer}

The Ganzi, Luhuo and Daofu country area, which belong to the north of Kang said by traditional Tibetan, is located in the core area of Ganzi Tibetan autonomous prefecture in Sichuan province. The region has been called "Huoer area", the local residents are called Huoer ${ }^{[2]}$. Among the people, they said "the fifth or the seventh tribe of Huoer."

The intent of Huoer is "the wind blows the ground cracks or given out by the wind blowing waste horn shell's cavity 'Huoer, the Huoer' voice", according to the folk legend.

\section{B. The Origin of the Huoer Culture}

Huoer culture refers to a series of culture that originated in the Huoer Zhang valley of Xianshui river. According to legend, sun river and moon river converge into three rivers on both sides of Xianshui, with the Maya shepherds, Seqiongzha people, Huoer people, formed the nirvana wood royal union. Appreciating the white conchs tribal alliance blows the white conchs, called "Wangtangjiabu nirvana wood Huoer Ba". Huoer is an ancient name which runs through the Xianshui river for thousands of years history and culture ${ }^{[3]}$

The origin of the legend culture Huoer straights in Taeho bokhi and Numas. Although it is difficult to confirm the folk hearsay is true or not, there is no doubt to cover a layer of mysterious veil on Huoer and Huoer culture. 


\section{THE OVERVIEW OF HUOER CULTURE}

Huoer culture riches in contents and variety of forms. The author summarizes the following Huoer culture system after did the actual investigation and read a large number of local works about Luhuo "Fig. 1".

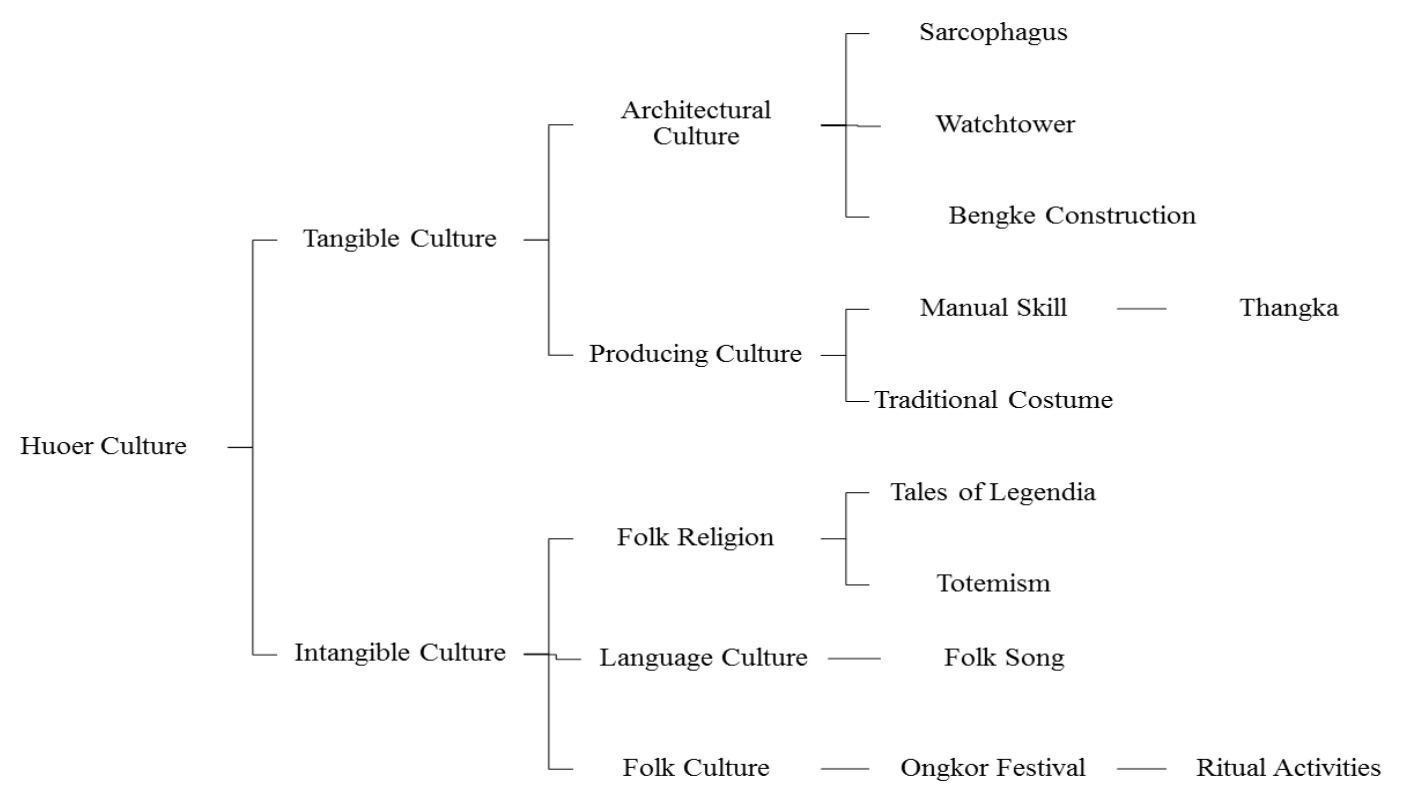

Fig. 1. Huoer culture system.

\section{A. Material Culture}

1) Architectural Culture - The Sarcophagus Culture: On the basis of the natural conditions, ways of ancient tribal burial are different. Funeral custom tends to reflect the clan tribal customs. For instance, they regard cremation as a symbol of ancient Qiang culture in most cases. River valley is located in Min river, Dadu river, Xianshui river and Yalong river. The four rivers upstream is an ancient agricultural area, where distributes sarcophagus tombs and immemorial residential tower buildings. Especially, from ancient Neolithic age to the Bronze age, different sarcophagus tombs are wildly distributed in three rivers and both sides area which consist of Xianshui river, Daqu river and Niqu river. And here also universally distributes old residential towers residue sites. It reflects the survival way of ancient Huoer considers sarcophagus buried as funeral customs and old residential towers for defense as their living customs.

Since the 1930s, a large number of sarcophagus tombs were successively found in Luhuo, varied from the Neolithic age to the Hang, Tang dynasty. The sarcophagus culture of Luhuo has lasted for 4500 years from the Neolithic age to the $8^{\text {th }}$ century. We describe Xianshui basin as an drastically ancient sarcophagus culture corridor and It's not a bit exaggerated to name Xianshui basin as the sarcophagus kingdom.

Because of long time span, Luhuo sarcophagus cultural sites unearthed relics covers all kinds of periods of the culture, origination, boom and bust. In addition, the relic site creates the brilliant Huoer immemorial civilization for its great scale, widespread and assembling basic types of sarcophagus system in Sichuan and Yunnan western plateau. It has profound influence in the southwest of the great ancient culture circle. Meanwhile, the relic site contains quite rich cultural connotations for its large number of culture relics varieties. The characteristics of unearthed relics are plain and original in early phase, fine and magnificent in the mid, multiple outstanding in later, provides a comprehensive materials on present race and ethnic art history study ${ }^{[4]}$.

2) Production Culture-Thangka: Thangka is an unique form of art in the Tibetan culture. It has distinct national characteristics, strong religious color and unique artistic style. Thangka sketches a sacred Buddha world with bright colors. Traditionally, pigments made of precious gems, including gold, silver, pearl, agate, coral, turquoise, malachite, vermilion and phytochrome such as saffron crocus, rheum officinale and indigo, these show the sanctity of Thangka. These natural ingredients provide a guarantee on its bright color and dazzle. Although after several hundred years, it still remains showy bright. Therefore, Thangka is regarded as a treasure of Chinese national art of painting, known as the Tibetan encyclopedia as well. At the same time, it is also the Chinese nation precious intangible culture heritage of folk art.

Huoer culture nourishes the Tibetan Karmagazi painting group grand master Lang Kajie (about 1610 AD), In the Huoer folk, there is still a tales of legendia of Lang Kajie magic into a painter.

Legend Lang dreams about Manjusri bodhisattvas chanting ritual and bath for him, teaching him painting skills secretly and given him brush plate. Lang finds his right hand holding the brush, leaves hand holding a plate when he wakes up, feeling the whole body easy and pleasure. Since then, his painting skills multiple and become exquisite from time to time. 
Lang Kajie painting style reaches the point of perfection from the common painting to the scratch painting and from the particular to the implicit learning. Lang leaves with lots of fine Thangka and immortal tales, and his descendants have continued into the $9^{\text {th }}$ generation. $<$ Nirvana> and <Buddha biography> are his masterpieces.

Nowadays, Thangka still is known and respected, this kind of magnificent art come down from ancient Huoer attracting a string of visitors to explore.

\section{B. Intangible Culture}

\section{1) Folk Religion}

\section{a) Tales of Legendia}

Every nation has its unique myths and legends. Taiwan historian Yang Bai said "we can learn the background of primitive life and culture reactions from the content of the myth". Huoer's fairy tales from "Abu creation" to Fuxi Nuwa "Flood day, brother and sister to marry", "North matchless magic" and "The birth of king of nirvana wood" throughout the history of the development of Huoer, one of the most famous tales is "Changyi come to live in Ruoshui".

Huoer folk has a legend in ancient times, a prince of on the Xianshui river and another tribe of the woman married. The child of Huoer, Prince Tangge became in charge of the nine hundred mountain gods, people all over the world every year must using blood for worshiping. Defy or no blood supply mission subordinates, the mountain deities will suffer severe scourge. In addition, Kham Huoer's autumn has to accept hail damage wheat ripe punishment. Huoer area's aborted children are going to be sent to color snow hand egg/seranxuedan land and wrapped with hands. Huoer area coated with red cream in the palm of the dead child, to seek escape scrutiny. Folk is still continued this custom ${ }^{[5]}$.

This short and precious gods story in folk Huoer, not only reflects the true cultural history from the side, showed farming Huoer national identity certain culture of mountain god in the context of history, but also profoundly reveals the essence of "myth is the soul of a nation".

\section{b) Totem}

Totem mentioned in Frasers classic <Kanae>, is "out of superstition to the material object of worship",[6]. Totem worship is always associated with certain totem mythology. Totem mainly treat living or non-living, ancestor or protector as the benefactor of their ancestors or human beings and the creator of all things in the form of oral account and letters. Totem retains many myths of all the ethnic groups in China.

The ancient Huoer admires frogs, and there is a legend that Nvwa use a frog to take place of the final piece. Therefore, "magical frog song and dance" comes from vibrant croaking, bold and unrestrained frog pose that Huoer uses for showing off the creation of the world (that later called the frog Guozhuang). Because frogs has to eat pests in the crops, so Huoer highly praise the frog for devotees and friends of The Creation. When crops harvest, human thanksgiving feast for the frog, they stop croaking and ready to hibernate. For this, the folk uses the metaphor "Autumn ripe, the frog mouth is closed and not to open" to describe people gratitude them without annoys.

At the same time, Huoer's worship of tigers and leopards the same as Fuxi Nuwa's worship. Huoer also advocates alpine ibex, roc an enormous legendary fish which could change into a roc, fire and mountain, etc. It is worth mentioning that Huoer advocates ecology and respects nature, so it embodies a natural worship of taking the sun as core. Meanwhile, from the ethnic advocate heaven evolved to the ethnic worship heaven, it also reflects that they are ecological adorer.

In the creation of world, ancient Huoer continues using a variety of soul sign, totem image and a variety of positive culture spirit to inspire descendants.

\section{2) Language Culture - the Hometown of Folk Songs}

Since Tibetan words appearing before, as the form of oral literature, folk songs have been widely circulated among the masses. In ancient Tibetan language, Huoer people are getting used to communicate with each other with folk songs.

Song of Huoer Tibetan areas without beginning, without composed of people, mostly all previous dynasties deliver mouth to mouth and teach heart to heart, Huoer's history is the history of walking around with the song. From generation to generation, dignified and ordinary are feel the suffering and joy in the song.

Folk songs of Tibetan Huoer is unadorned, simple, without rendering, original, whether it is a chanting, love song or song of hoop hexagrams. Although the style is not the same, it also has the same effect. Huoer enjoy the state of mind which Keeps peaceful and leisurely heart for pleasure and loses themselves in charm melody between heaven and earth. In Tibetan proverbs "people cannot sing, like a yak", which shows the nature of being good at singing and dancing of Tibetan ${ }^{[7]}$.

Folk song of Huoer covers many aspects, such as love, life, paean and so on. People often release self soul in the song. Song of the place where people gather together, everywhere is full of laughter. Because their song expresses with heart, the folk song is Clueless and has unique artistic style.

\section{3) Folk Culture}

\section{a) Festival}

The ancient Huoer people admire the heavens and the earth. For example, "Huoer elyos" custom has been passed down from nimble ancestors to now. What's more, the "shrimp pull Tuo" heaven dam has already lingered for thousands of years. It is said that the damn used to kill deer to worship heaven in Anayixicuojie era. Thereafter, here is regarded as a few generations tribe kingdom's capital. For kingdom sites, there has been a geomantic treasure land so far. Besides, there are two old host, and both are the symbol of worshipping and observing geomancy and astronomical phenomena during thousands of years. From Niqu river to easy day groove of the bon religion temples, modern continues have their own characteristics worship and religious rites of "hail prevention, frost resistance and rain praying". Agriculture folk "trap client honk" mucking out worship festival, have highlighted the old rich farming civilization characteristic culture. Related 
successors are good at astronomical calendar calculation and dancing ghost drama, disappeared until the $50 \mathrm{~s}$ last century.

Also according to the legend prince Huoer and Huoer Nyenchen Tanglha multiply the offspring in Qamdo to mount tunggula area. Then these offspring become the leaders of king's army of the Lhasa area and they often revenge and harass Huoer native people of Kang. Offspring was for Nyenchen Tanglha mountain deity, forcing the people of Xianshui river in Huoer area and worshiping for Nyanchen Tanglha mountain deity per annually in the season fall to pray for the autumn crops to avoid being destroyed by hail. This inheritance of autumn "ongkor" feata in Huoer valley, yet in Luhuo folk still popular, evolves into today's "ongkor festival".

\section{b) Folk Dancing}

According to the previous mention, people admire the lengend that Nvwa use the frog's four feet support the earth steadily, then deriving a Huoer "the magical frog dance"(that later called the frog Guozhuang). Ancestors' Huoer's surname, men's hair bun is turquoise and ivory and wrist distort brachial set of full metal bracelet, while women put braids on blue headscarf. With decoration, such as turquoise and yellow amber, they surround with dancing "The goddess NuWa", the sound of the sky, dancing, indomitable spirit, development to the toad around the osmanthus Xuan of supernatural and mysterious power and infatuatedly desire into bizarre wonderland of dancing with the gods in the moon.

The carpenter dancing style of the stooped and hunchbacked originats in Kang and imitates the frogs dance. Dangling bouncing, heroic, free and easy dance posture, bend waist bow back, bold and unrestrained, shock song, incisively and vividly shows the frog dance this kind of indomitable spirit, comfortable Xuan posture and passionate dedication of creation. It is a pity that the frog dance has disappeared in the long history.

\section{HuOER CUlture APPliCATION IN LANDSCAPE ARCHITECTURE}

Regional traditional culture is the soul of landscape architecture design. Only when the designers have a soul, can they obtain the resonance of the local residents and attract more tourists. And at the same time, the landscape architecture is also one of the best carriers, bearing and carry forward the regional culture. After long years of Huoer culture, should not be buried, luster should be in this land.

The content of the Huoer cultural present secularistic, diversified characteristics, different types or forms of culture in landscape design also embody the different applications.

Application of overall summarizes three main aspects: inheriting human and the nature harmonious ecological environment protection, building a unique cultural landscape and promoting economic development of tourism function.

\section{A. Inheriting the Concept of Ecological Protection}

In history, cultural Huoer is the father of ecological civilization. Because the ancient people advocate natural Huoer and respect nature, so we now retain the beautiful natural environment in the Xianshui river. Huoer admire the heavens and earth, the moon and sun. For Huoer, nature is mysterious and unknowable to Huoer. They regard the natural and the forces of nature as objects of worship which having sign of life, will-power and great ability, and promote worship ghosts and animism view of spirit. At the same time, the Huoer sarcophagus burial customs and belief of standing stumpage for god sculpture for god "Fig. 2", both of them expresses Huoer ecological and natural view. Such natural worship creates the Xianshui river beautiful matural environment and such a belief is in guiding today's Luhuo protection of this mysterious land. With the establishment of beautiful wetland park of Huoer Zhang valley, its beautiful scenery resource not only is of use, but also should be protected. Meanwhile, the establishment of the park will also take ecological view of Huoer to spread all over the world, and advocat people to protect ecology and respect nature.

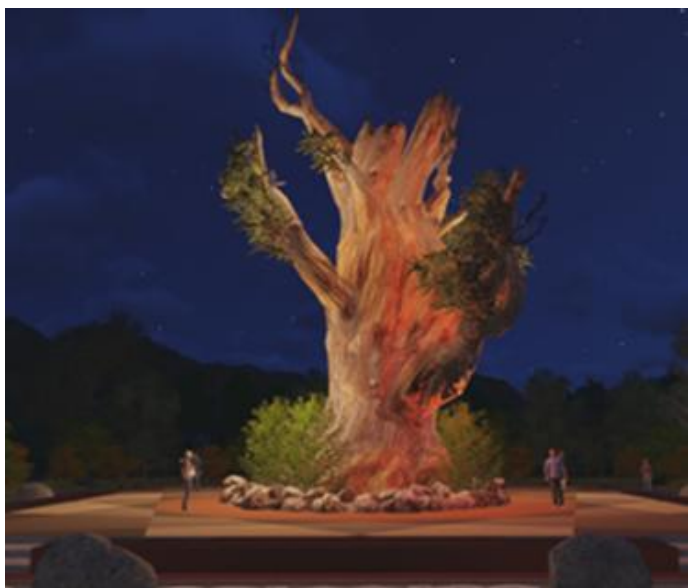

Fig. 2. "Standing stumpage for god" sculpture. Image source: the author custom painting.

\section{B. Building the Unique Cultural Landscape}

Regional culture element is the punchline of cultural landscape with local characteristics and Huoer culture has a lot of totem element. Some abstract extraction totem elements is as a kind of adornment language to apply in every aspect of people's life. Totem also provides a rich resource for landscape design. In the construction of landscape space, using the totem paving, reliefs and culture column can greatly improve the cultural atmosphere of space ${ }^{[8]}$. At the same time, in Luhuo's famous "square Huoer culture" just passes through the Huoer totems to shape full relief, relief group and culture column as the theme of the series of sculpture art. It reflects Huoer initiative nation spirit. The physical form and spirit in the form of Huoer cultural square, which trace the origin and development of Huoer $\mathrm{Ba}$, constitute a cultural garden, establish a stable mechanism of cultural foundation and the flow of culture in Luhuo and promote Huoer cultural square become the source of symbolic public places. Not only cultural totem, but Huoer cultural full of rich myths, production techniques and folk customs, the whole can be expressed through the narrative form of landscape in the landscape architecture "Fig. 3" and "Fig. 4". 


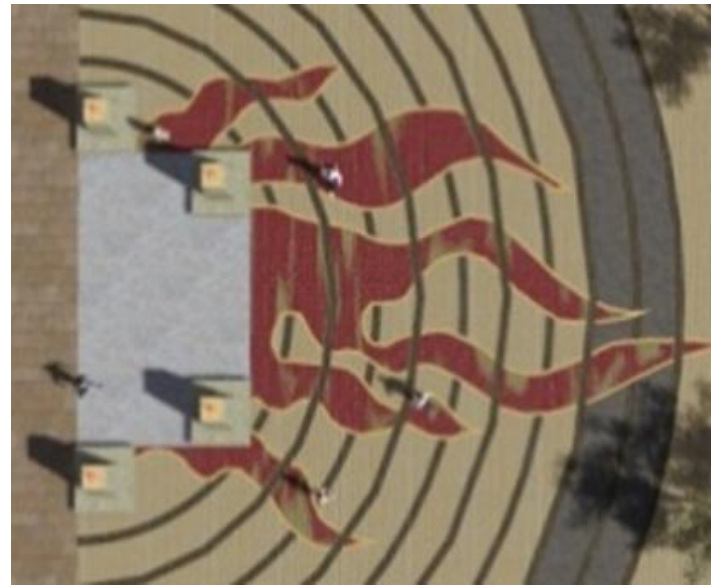

Fig. 3. The performance of fire totem in culture square. Image source: the author custom painting.

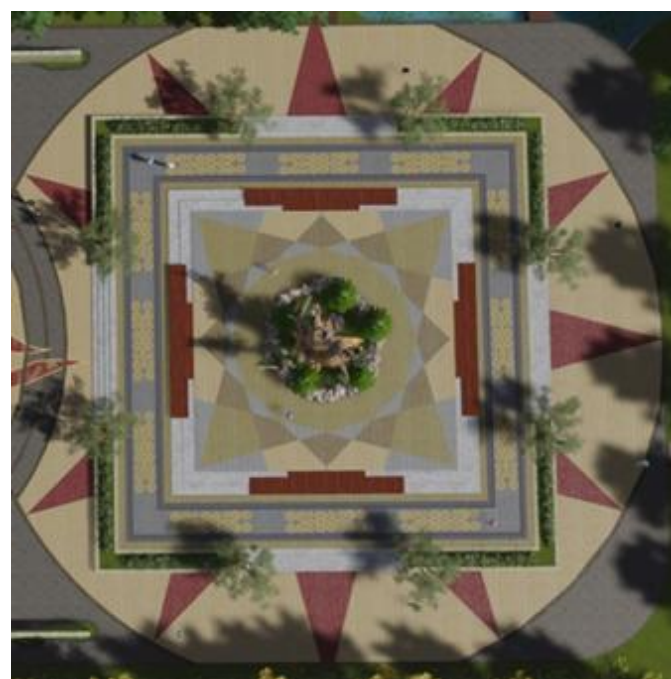

Fig. 4. The manifestation of the sun totem in the cultural square. Image source: the author custom painting.

\section{Driving the Development of Tourism}

Natural scenery, folk customs and traditional festivals of minority both are key factors to promote the development of tourism. Huoer culture goes back to ancient times. Although is not known, digging Tibetan and $\mathrm{Yi}$ ethnic corridor culture promotes the development of the Huoer culture in recent years. However, the mysterious veil on cultural Huoer of that can be help to promote the development of local tourism.

According to the analysis about the present situation of the tourism market and the forecast for the future development trendency, combining with the Huoer cultural tourism resources endowment and tourism product consumption preference, we can roughly summarize into the following two points:

First, ethnic culture tourism products is the evergreen tree of the tourism market. The basic demands of tourists for travel is hunting for novelty. That is to say through traveling to gain the knowledge and experience which has never been in people' life, then we can have fun. Ancient and mysterious Huoer culture, immemorial sarcophagus history, etc., all of these can arouse people exploratory requirements.

Second, the tourism experience of local conditions and customs. Huoer of traditional customs and habits and large festival, such as the ongkor festival, large-scale ritual activities, as well as traditional folk dance and song, etc. This is what is different with other areas, as well as the longing of tourists.

Marked by bold, self-entertainment, optimistic plateau artistic appeal. Passing down folk songs and dances such as generation reverberate through flat valley and grassland folk songs, hoop hexagrams, labor song, Guozhuang, god ghost drama, antiphonal singings, cry for sacrifice, flute and kouxian and hard to count rap stories, riddles, proverbs, myths, legends and folk literature, has created an opportunity for the development of tourism.

Huoer culture has relative uniqueness and exclusiveness, is the symbol of tourism culture identification in Luhuo, is the key elements in the landscape architecture planning and design should be considered.

\section{CONCLUSION}

The historical destiny of ancient clan Huoer, is slowly shunted and integrated into from immemorial and prominent position, then weakening down to the edge of the long history. However, Huoer nation being regarded by later powerful nations as foreign, still in different regions have Huoer family name, last name, place name, folk custom lasting. If we say there are many ethnic blend of history in the human civilization coordinate diagram, then, ethnic group with Huoer as their last name is lasting for the longest of the most popular and native ancient clan in the Chinese national culture history and it will never disappear.

Through the overview of Huoer culture, this article combines with its application in landscape design explore the implementation path which combines landscape design with regional traditional elements. Regional traditional culture makes the landscape design have a soul, while landscape design will carry forward the regional traditional culture. Only when the two aspects combine together nicely, can we better inherit this cultural wealth and can landscape architecture be given better vigor and vitality.

\section{REFERENCES}

[1] Cao Ting. Clan imagination, culture genes and settlement landscape form-Zhang Guying village settlement landscape form typology research. Central south forestry university of science and technology, 2014

[2] Jia Qing. Annals of Sichuan volume of Wu Beizhi. Toast. Chengdu: Bashu publishing house, 1984

[3] Ran Changsheng. The riddle of the Xianshui river Huoer . Chengdu: Bashu publishing house, 2014

[4] Ran Changsheng. Accumulation of furnace huo ancient civilization. Chengdu: Sichuan people's publishing house, 2007

[5] Bo Yang. The Chinese survey. Jilin: The time literature and art publishing house, 1987.

[6] Fraser. Golden. Beijing: The popular literature and art publishing house, 1998. 
[7] He Zexiao, Qiu Wenli. "Ancient voices". Beijing: Central literature publishing house, 2007.

[8] XiaoYan. Qiang folk belief and its social value function. Journal of southwest university for nationalities (humanities and social science edition), 2015 (3). 